изворите во повеќе наврати, како и бројните фактографски грешки. Иако интересно, па на моменти дури и возбудливо четиво, поради сериозните недостатоци книгата не успева да ги исполни зацртаните цели на уредниците на едицијата, ниту пак верувам дека би можела да послужи како соодветен увод, односно помагало за пошироката читателска публика, или пак за оние што допрва почнуваат да навлегуваат во прашањето за римската експанзија на истокот.

Стефан Пановски

Институт за национална историја, Скопје

\title{
МАКЕДОНСКИ ПРЕВОДИ НА ДЕЛА ОД СТАРОГРЧКИ И ЛАТИНСКИ ЈАЗИК
}

\section{1. ЕПИКА (ЕРICA)}

\section{Вергилиј (Vergilius)}

Ajнеида (AENEIS). Препев од латински, Љубинка Басотова, предговор Елена Колева. Скопје: Култура,1999.

\section{Овидиј (Ovidius)}

Преобразби (METAMORPHOSES). Препев од латински, Љубинка Басотова. Скопје: Три, 2002.

Прличев, Г. C. (Prlichev, G. S.)

Мартолозот (O ARMATOLOS). Препев од старогрчки, М. Д. Петрушевски. Скопје: Македонска книга, 1983.

Скендербеј (SKENDER BEY). Препев од старогрчки, М. Д. Петрушевски. Скопје: Македонска книга, 1974.

\section{Хесиод (Hesiodus)}

Дела и дни (OPERA ET DIES). Препев од старогрчки, Витомир Митевски. Скопје: Култура, 1996.

Теогонија (THEOGONIA). Препев од старогрчки, коментар и индекс Марија Чичева-Алексиќ. Скопје: Сигмапрес, 2001.

\section{Хомер (Homerus)}

Избор од „Илијада” и „Одисеја” (ILIADIS ET ODYSSEAE CARMINA SE$L E C T A)$. Превод и препев од старогрчки, Михаил Д. Петрушевски. Скопје: Култура, 1953.

Избор од “Илијада" (ILIADIS CARMINA SELECTA). Превод и препев од старогрчки, Михаил Д. Петрушевски. Скопје: Просвета, 1969.

Илијада (ILIAS). Препев од старогрчки, Михаил Д. Петрушевски. Македонска книга, Скопје, 1982.

Oдисеја (ODYSSEA). Од старогрчкиот оригинал превел и препеал Михаил Д. Петрушевски. Ракописот го приредиле за печат Калиопа Петрушевска и Владимир Петрушевски. Скопје: Магор, 2008. 
Хомерски химни (Нуmпі Нотегісі).

Хомерски химни (HYMNI HOMERICI). Превод од старогрчки, предговор, белешки, коментар и индекс со објасненија Марија Чичева-Алексиќ. Сигмапрес, Скопје 2011.

\section{2. ЛИРИКА (LYRICA)}

Антологија на хеленската лирика (ANTHOLOGIA LYRICA GRAECA). Предговор, вовед и препев од старогрчки, Елена Колева. Скопје: Зумпрес, 1996.

Катул (Catullus)

Поет на љубовта и омразата, превод од латински Миле Богески, Прилеп: Кубоа 1998.

Мартијал (Martialis)

Enиграми (EPIGRAMMATA). Препев од латински и белешки, Миле Богески. Скопје: Култура, 1996.

Римска поезија (РОEMATA LATINA). Препев од латински и белешки: Љубинка Басотова. Скопје: Панили, 2012.

\section{3. ДРАМА (DRAМАТІCA)}

\section{а. Трагедија (Tragoedia)}

\section{Ајсхил (Aeschylus)}

Opecmuja (ORESTEIA). Препев од старогрчки, предговор и белешки, Даница Чадиковска. Скопје: Метафорум, 1994.

Прибегарки, Персијци, Седумтемина против Теба (SUPPLICES, PERSAE, SEPTEM CONTRA THEBAS). Препев од старогрчки и белешки, Даница Чадиковска. Скопје: Мисла, 2000.

Прикованиот Прометеј (PROMETHEUS VINCTUS). Препев од старогрчки, предговор и белешки, Михаил Д. Петрушевски. Скопје: Македонска книга, 1978.

\section{Еврипид (Euripides)}

Алкестида, Елена, Споулавениот Херакле (ALCESTIS, HELENA, HERCU$L E S)$. Превод од старогрчки, Даница Чадиковска. Скопје: Евро Балкан Прес, 2003.

Електра, Орест, Ифигенеја во Таврида (ELECTRA, ORESTES, IPHIGENIA TAURICA). Превод од старогрчки, Даница Чадиковска. Скопје: Зумпрес, 1998.

Медеја (MEDEA). Препев од старогрчки, предговор и белешки, Катерина Колозова. Скопје: Метафорум, 1994.

Хекаба, Андромаха, Тројанки (HECUBA, ANDROMACHA, TROIADES). Превод од старогрчки, Даница Чадиковска. Скопје: Три, 2002.

Хиполит, Ифигенија во Авлида, Бакхи (HIPPOLYTUS, IPHIGENIA AULI$D E N S I S, B A C H A E)$. Препев од старогрчки, Даница Чадиковска. Скопје: Зумпрес, 1995.

\section{Софокле (Sophocles)}

Антигона, Филоктет (ANTIGONE, PHILOCTETES). Препев од старогрчки, Љубинка Басотова. Скопје: Мисла, 1990. 
Ojдип тиранин, Ојдип на Колон (OEDIPUS TYRANNUS, OEDIPUS COLONEUS). Препев од старогрчки, Даница Чадиковска. Скопје: Мисла, 1991.

Tрахинки, Ајант, Електра (TRACHINIAE, AJAX, ELECTRA). Препев од старогрчки, Даница Чадиковска. Скопје: Зумпрес, 1995.

\section{б. Комедија (Comoedia)}

\section{Аристофан (Aristophanes)}

Богатство (PLUTUS). Предговор, препев од старогрчки и белешки Даниела Тошева-Николовска. Скопје: Три, 2015.

Жаби (RANAE). Превод од старогрчки, предговор и коментар, Весна Томовска. Скопје: Табернакул, 2000.

Жаби, Птици, Облаци, Лисистрата. (RANAE, AVES, NUBES, LYSISTRA$T E)$. Превод од старогрчки на Жаби и Лиситрата Весна Томовска, превод од старогрчки на Птици и Облаци Даниела Тошева-Николовска. Поговор Весна Томовска. Скопје: Три, 2013.

Жени во собрание (Еклесиаsуси) (ECCLESIAZUSAE). Предговор, препев и превод од старогрчки, белешки и коментари Валериј Софрониевски. Скопје: Три, 2013.

Лисистрата (LYSISTRATE). Превод од старогрчки Валериј Софрониевски. Скопје: Три, 2016.

Облаци (NUBES). Превод од старогрчки, предговор и објаснувања, Ивица Весов. Скопје: Аз-Буки, 2004.

Ocu (VESPAE). Препев од старогрчки, предговор и белешки Даниела Тошева-Николовска. Скопје: Профундум, 2011.

Славенички на Тесмофории (THESMOPHORIAZUSAE). Превод од старогрчки Валериј Софрониевски. Скопје: Три, 2014.

\section{Менандер (Menander)}

Комедии и фрагменти (COMOEDIAE ET FRAGMENTA). Препев од старогрчки, белешки и предговор, Даниела Тошева-Николовска. Скопје: Профундум, 2008.

\section{Плаут (Plautus)}

Војникот фалбаиија (MILES GLORIOSUS). Превод од латински, белешки и предговор, Маргарита Бузалковска-Алексова. Скопје: Профундум, 2007.

Грне (AULULARIA). Препев од латински на македонски Васил Буковски, Јовица Гроздановски, Марија Манасиевска, Мирјана Савиќ. Скопје: Профундум, 2010.

Менехми, Скржавецот, Tрговеи (MENAECHMI, AULULARIA, MERCATOR). Превод од латински јазик, Миле Богески. Заробеници (CAPTIVI). Препев од латински јазик, Маргарита Бузалковска-Алексова. Скопје: Евро Балкан Прес, 2003.

Сеништа (MOSTELLARIA). Превод од латински, предговор и белешки Елена Џукеска. Скопје: Профундум, 2011.

\section{Терентиј (Terentius)}

Девојката од Андрос, Евнух, Свекрва, Браќа (ANDRIA, EUNUCHUS, $A D E L P H O E)$. Превод од латински јазик Миле Богески. Скопје: Евро Балкан Прес, 2005. 


\section{в. Сатирски драми (Satyrica)}

Сатирски драми: Еврипид Киклоп, Софокле Ловечки кучиња (DRAMATA SATYRICA: EURIPIDES CYCLOPS, SOPHOCLES ICHNEUTAE). Препев од старогрчки, предговор и белешки Даниела Тошева-Николовска. Скопје: Магор, 2012.

\section{4. ФИЛОСОФИЈА (РНILOSOРНІА)}

\section{Абелар, Пјер (Pierre Abelard)}

Историја на моите несреќи (HISTORIA CALAMITATUM). Превод од латински: Весна Димовска-Јањатова. Скопје: „Конгресен сервисен центар“; Битола: „Микена“,Скопје: „Макавеј“, 2012.

\section{Аврелиј Августин (Aurelius Augustinus)}

За државата божја кн. VI-X (DE CIVITATE DEI). Превод од латински Љубинка Басотова. Скопје: Култура, 2008.

\section{Аврелиј Августин (Aurelius Augustinus)}

Исповеди (CONFESSIONES). Превод од латински Елена Весова-Колоска. Скопје: Макавеј, 2007.

Разговори со самиот себе (SANCTI AURELII AUGUSTINI SOLILOQUIO$R U M$ LIBRI DUO). Превод од латински: Марија Манасиевска. Скопје: АРC СТУДИО, 2015.

\section{Аријан (Arrianus)}

Прирачникот на Епиктет (EPICTETOU ENCHEIRIDION). Превод од старогрчки и предговор, Витомир Митевски. Скопје: Матица македонска, 2008.

\section{Аристотел (Aristoteles)}

Аристотел: Избор (ARISTOTELES,OPERA SELECTA). Увод, превод од старогрчки, предговор и речник, Витомир Митевски. Скопје: Матица македонска, 1998.

Аристотел: Избор (ARISTOTELES,OPERA SELECTA). Увод, превод од старогрчки, предговор и речник, Витомир Митевски. Скопје: Матица македонска, 2003.

За душата (DE ANIMA). Превод од старогрчки, коментар и белешки, Маргарита Бузалковска-Алексова. Скопје: Магор, 2006.

За небото (DE CAELO). Превод од старогрчки, Елена Џукеска. Скопје: АзБуки, 2005.

За поетиката (РОЕТICA). Превод од старогрчки, предговор на авторот и коректура, Михаил Д. Петрушевски. Скопје: Македонска книга, 1979.

За создавањето и уништувањето (DE GENERATIONE ET CORRUPTIO$N E)$. Превод од старогрчки, белешки и предговор, Елена Џукеска. Скопје: Профундум, 2007.

Kaтегории (CATHEGORIAE). Превод од старогрчки јеродјакон Виктор Теодоростудит. Скопје: Табахон, 2012.

Метафисика (METAPHYSICA) прв дел (книги I, II, III, IV) Превод од старогрчки јеродјакон Виктор Метафраст. Скопје: Табахон, 2013.

Метеорологија (METEOROLOGICA). Превод од старогрчки, белешки и предговор. Елена Џукеска. Скопје: Профундум, 2009. 
Никомахова етика (ЕTHICA NICOMACHEA). Превод од старогрчки и предговор, Елена Колева. Скопје: Три, 2003.

Политика (POLITICA). Превод од старогрчки, коментар, белешки и поговор, Маргарита Бузалковска-Алексова и Елена Џукеска. Скопје: Слово, 2006.

Pеторика (RHETORICA). Превод од старогрчки и коментари, Весна Томовска. Скопје: Македонска книга, 2002.

\section{Аурелиј, Марко (Marcus Aurelius)}

За самиот себе (COMMENTARIORUM QUOS IPSI SIBI SCRIPSIT). Превод од старогрчки, белешки и коментари, Наталија Поповска. Скопје: Три, 2005.

\section{Баумгартен (Baumgarten)}

Философски медитации (MEDITATIONES PHILOSOPHICAE). Превод од латински и белешки, Весна Димовска-Јањатова. Скопје: Магор, 2004.

\section{Кикерон (Cicero)}

За должностите (DE OFFICIIS). Превод од латински и белешки, Светлана Кочовска. Скопје: Магор, 2005.

Философски расправи - За пријателството, За староста, За презирот кон смртта (DE AMICITIA, DE SENECTUTE, DE CONTEMNENDA MOR$T E)$. Превод од латински и белешки, Љубинка Басотова. Скопје: Македонска книга, 1983.

Философски расправи: За крајностите на доброто и злото. Тускулански pacnpaвu (DE FINIBUS BONORUM ET MALORUM, TUSCULANAE DISPUTATIONES). Превод од латински, Љубинка Басотова. Скопје: Три, 2003.

\section{Лукретиј Кар (Titus Lucretius Carus)}

За природата на нештата (DE RERUM NATURA). Препев од латински јазик, Љубинка Басотова. Скопје: Култура, 2006.

\section{Платон (Plato)}

Горгија (GORGIAS). Превод од старогрчки и коментар, Валериј Софрониевски. Скопје: Бигосс, 2004.

Закони (LEGES). Превод од старогрчки и предговор, Елена Колева. Скопје: Три, 2007.

Кратил (CRATYLUS). Превод од старогрчки, Весна Томовска. Скопје: Магор, 2006.

Kpuтuja (CRITIAS). Превод од старогрчки и коментар: Марјан Калевски. Скопје: Матица Македонска, 2012.

Менон (MENO). Превод од старогрчки Валериј Софрониевски, Скопје: Три, 2017.

Одбраната Сократова, Критон, Фајдон (APOLOGIA SOCRATIS, CRITO, $P H A E D O)$. Превод од старогрчки и белешки, Елена Колева. Скопје: Македонска книга, 1983.

Писма (EPISTULAE). Превод од старогрчки јазик, предговор, белешки и коментари Весна Томовска. Скопје: Магор, 2015.

Политеја (RESPUBLICA). Превод од старогрчки, предговор, коментар и белешки, Елена Колева. Скопје: Три, 2002.

Протагора, Евтифрон, Ион (PROTAGORAS, EUTHYPHRO, ION). Превод од старогрчки, предговори, белешки и објаснувања, Елена Колева. Скопје: Култура, 1994. 
Симпосиумска еротологија. Платон, Симпосион (Plato, SYMPOSIUM). Ксенофонт, Симпосион (Xenophon, SYMPOSIUM). Превод од старогрчки, предговор, белешки и објасненија, Елена Колева. Скопје: Култура, 2008.

Coфucm (SOPHISTA). Превод од старогрчки Ивица Весов. Скопје: Азбуки, 2008.

Teajmem (Theaetetus). Превод од старогрчки, предговор и белешки Валериј Софрониевски. Скопје: Профундум, 2011.

Tuмaj (TIMAEUS). Превод од старогрчки и предговор, Витомир Митевски. Скопје: Аз-буки, 2005.

\section{Порфириј (Роrphyrius)}

Увод и коментари за Категориите на Аристотел (IN ARISTOTELIS CATEGORIAS COMMENTARIUM). Превод и белешки од старогрчки јазик Даниела Тошева-Николовска. Скопје: АРС СТУДИО, 2015.

\section{Претсократовци}

Почеточи на западната философија. (PRAESOCRATICA). Превод од старогрчки, Витомир Митевски. Скопје: Матица македонска, 1999.

\section{Сенека (Seneca)}

За блажениот живот (DE VITA BEATA). Превод од латински, Биљана Чалоска-Караевска. Скопје: Три, 2003.

За гневот (DE IRA). Превод од латински Биљана Чалоска. Скопје: Магор, 2003.

\section{Хераклит (Heraclitus)}

Хераклит. Превод од старогрчки, В. Митевски. Скопје: Матица македонска, 1997.

\section{5. ИСТОРИОГРАФИЈА}

\section{Аријан (Arrianus)}

Александровата анабаса (ALEXANDRI ANABASIS). Превод од старогрчки, Маргарита Бузалковска-Алексова. Скопје: Патрија, 2000.

Индија: враќаъето на Александар од Индија (INDICA). Превод од старогрчки Ема Андоновска. Скопје: Икона, 2011.

\section{Барлети, Марин, (Marinus Barletius)}

Скендербег (HISTORIA DE VITA ET GESTIS SCANDERBEGI EPIROTARUM PRINCIPIS). Превод од латински и белешки, Љубинка Басотова и Весна Димовска-Јањатова. Скопје: Култура, 2008.

\section{Јустин (Iustinus)}

Филиповата историја (EX TROGO POMPEIO HISTORIAE PHILIPICAE). Превод од латински, Љубинка Басотова. Скопје: Патрија, 2000.

\section{Kaecap (Caesar)}

Александриска војна (DE BELLO ALEXANDRINO). Превод од латински јазик, предговор и белешки, Силвана Величковска и Јадранка Јованова. Скопје: Профундум, 2008.

Белешки за галската војна (COMMENTARII DE BELLO GALLICO). Превод од латински, Љубинка Басотова и Валериј Софрониевски. Скопје: Три, 2000. 


\section{Квинт Куртиј Руф (Quintus Curtius Rufus)}

Историја на Александар Македонски (HISTORIAE ALEXANDRI MAGNI). Превод од латински јазик, Љубинка Басотова. Скопје: Патрија, 1998.

\section{Ксенофонт (Xenophon)}

Aнабаса (ANABASIS). Превод од старогрчки и белешки Д. Боцевски. Предговор В. Томовска. Скопје: Македонска литера, 2016.

\section{Ливиј (Livius)}

Oд основањето на градот Рuм (AB URBE CONDITA). Превод од латински, предговор и белешки, Весна Калпаковска. Скопје и Мелбурн: Матица македонска, 2000.

\section{Плутарх (Plutarchus)}

Напоредни животописи (VITAE). Превод од старогрчки, Војислав Саракински. Коментари, Наде Проева. Скопје: Евро-Балкан Прес, 2008.

\section{Псевдо-Калистен (Pseudo-Callisthenes)}

Животот и делата на Александар Велики (GESTA ALEXANDRI). Превод од старогрчки, предговор и белешки, Весна Димовска-Јањатова. Скопје: Слово, 2008.

\section{Салустиј Крисп (Sallustius Crispus)}

За заговорот на Катилина (DE CONIURATIONE CATILINAE). Превод латински, белешки и предговор. Билјана Ивановска. Скопје: Профундум, 2009.

\section{Светониј (Suetonius)}

Дванаесетте римски цареви (DE VITA CAESARUM). Превод од латински јазик и белешки, Весна Димовска Јањатова и Војислав Саракински, предговор, Весна Димовска Јањатова. Култура, Скопје, 2001.

\section{Такит (Tacitus)}

Анали (ANNALES). Превод од латински и поговор, Љубинка Басотова. Скопје: Три, 2005.

\section{Такит (Tacitus)}

Германија и Агрикола (GERMANIA, AGRICOLA). Превод од латински јазик, предговор и белешки, Весна Димовска Јањатова и Војислав Чанчаревиќ. Скопје: Култура, 1999.

\section{Херодот (Herodotus)}

Историја (HISTORIAE). Превод од старогрчки, предговор, белешка за писателот и делото и коментари на текстот, Даница Чадиковска. Скопје: Зумпрес, 1998.

\section{VARIA}

\section{Ajcon (Aesopus)}

Басни (FABULAE). Превод од старогрчки, Валериј Софрониевски. Скопје: Три, 2008.

\section{Аполодор (Apollodorus)}

Библиотека (BIBLIOTHECA). Превод од старогрчки, белешки и предговор. Весна Томовска. Скопје: Македонска реч, 2009. 
Апулеј (Apuleius)

Mетаморфози (METAMORPHOSEON LIBRI XI SIVE ASINUS AUREUS). Превод од латински јазик, предговор и белешки, Весна Димовска-Јањатова. Скопје: Култура, 2003.

Апулеј (Apuleius)

Meтаморфози (METAMORPHOSES). Превод од латински: Весна Димовска-Јањатова. Скопје: „Конгресен сервисен центар“, Битола: „Микена“ и Скопје: „Макавеј“, 2012.

\section{Витрувиј (Vitruvius)}

Десет книги за архитектурата (DE ARCHITECTURA). Превод од латински јазик, Љубинка Басотова. Скопје: Зумпрес, 1998.

\section{Деметриј (Demetrius)}

За јазичниот израз (DE ELOCUTIONE). Превод од старогрчки Весна Томовска. Скопје: Три, 2016.

\section{Демостен (Demosthenes)}

Говори (ORATIONES). Избор, предговор и превод од старогрчки, Даница Чадиковска. Скопје: Култура, 1995.

\section{Диоген Лаертиј (Diogenes Laertius)}

Животите и мислењата на славните философи (DE CLARORUM PHILOSOPHORUM VITIS, DOGMATIBUS ET APOPHTHEGMATIBUS LIBRI DE$C E M)$. Превод од старогрчки, Елена Весова Колоска и Ема Андоновска. Скопје: Аз-Буки, 2004.

\section{Еразмо Ротердамски (Desiderius Erasmus)}

Пофалба на лудоста (STULTITIAE LAUS). Од латински преведе и белешките ги напиша Љубинка Басотова. Скопје: Култура, 1990.

\section{Кикерон (Cicero)}

Говори против Катилина (Катилинарија) (IN CATILINAM ORATIONES). Превод од латински, предговор и белешки, Љубинка Басотова. Скопје: Метафорум, 1994.

Избрани писма (EPISTULAE). Превод од латински, белешки и коментари: Светлана Кочовска. Скопје: Три, 2014.

\section{Лонг (Longus)}

Дафнид и Хлоја (DAPHNIS ET CHLOE). Превод од старогрчки, Ивица Весов. Скопје: Конгресен сервисен центар, 2011.

\section{Лукијан од Самосата (Lucianus Samosatensis)}

Како треба да се пишува историја (QUOMODO HISTORIA CONSCRIBEN$D A S I T)$. Превод од старогрчки и воведна студија, Војислав Саракински. Скопје: Аз-Буки, 2004.

\section{Петрониј (Petronius)}

Сатирикон (SATYRICON). Превод од латински: Весна Димовска-Јањатова. Скопје: Три, 2012.

Сатирикон (SATYRICON). Превод од латински, Ивица Весов. Скопје: Македонска книга, 2003.

\section{Псевдо-Лонгин (Pseudo-Longinus)}

За возвишеноста (DE SUBLIMITATE). Превод од старогрчки, белешки и коментари, Весна Томовска-Митровска. Скопје: Магор, 2004. 


\section{Сведенборг, Емануел (Emanuel Swedenborg)}

За небото и пеколот (DE CAELO ET EIUS MIRABILIBUS ET DE INFERNO, EX AUDITIS ET VISIS). Превод од латински: Весна Димовска-Јањатова. Скопје: Три, 2013.

\section{Св. Јован Златоуст (Ioannes Chrysostomus)}

Писма до Олимпијада (EPISTULAE AD OLYMPIADEM). Превод од старогрчки Оливера Димовска. Скопје: Макавеј, 2015.

\section{Сенека (Seneca)}

Потиквувањето на божествениот Клаудиј (APOCOLOCYNTOSIS DIVI CLAUDII). Превод од латински, Наталија Поповска. Скопје: Или-или, 2009.

\section{Страбон (Strabo)}

Географија (GEOGRAPHICA). Превод од старогрчки, Наталија Поповска. Скопје: Темплум, 2011.

\section{Tеофраст (Theophrastus)}

Xapaкmepu (CHARACTERES). Превод од старогрчки, увод, белешки и коментари, Марија Чичева-Алексиќ. Скопје: Слово, 2007.

\section{Хеленски мимови (MIMI GRAECI)}

Хеленски мимови (MIMI GRAECI). Превод од старогрчки: Даниела ТошеваНиколовска. Скопје: Магор, 2016.

\section{Хигин (Hyginus)}

Muтови (FABULAE). Превод од латински: Светлана Кочовска. Скопје: Три, 2016.

\section{Хоратиј (Horatius)}

За поетската уметност (ARS POETICA). Препев од латински, Љубинка Басотова, предговор и илустративни текстови, Елена Колева. Скопје: Мисла, 1995. 